\title{
Correction to: Thermal comfort in urban spaces: a cross-cultural study in the hot arid climate
}

\author{
Faisal Aljawabra ${ }^{1} \cdot$ Marialena Nikolopoulou $^{2}$
}

Published online: 15 November 2019

(C) ISB 2019

Correction to: International Journal of Biometeorology (2018) 62 (10): 1901-1909 https://link.springer.com/article/10.1007/s00484-018-1592-5

The article was published without special issue designation resulting in regular issue compilation. The author group and publisher regret the error and ask the article to be considered for Special Issue: Subjective approaches to thermal perception.

Publisher's note Springer Nature remains neutral with regard to jurisdictional claims in published maps and institutional affiliations.

The online version of the original article can be found at https://doi.org/ $10.1007 / \mathrm{s} 00484-018-1592-5$

Faisal Aljawabra

Faisal.Aljawabra@bath.edu

1 Department of Architecture and Civil Engineering, University of Bath, Bath BA2 7AY, UK

2 Kent School of Architecture, University of Kent, Canterbury CT2 7NR, UK 